\title{
THE FIRST RECORD OF PROMYIALGES PARI FAIN, 1965 (ACARIFORMES: EPIDERMOPTIDAE) FROM THE LOUSE FLY ORNITHOMYA AVICULARIA L., 1758 (DIPTERA: HIPPOBOSCIDAE) IN EUROPEAN RUSSIA
}

\author{
Aleksandra A. Yatsuk* and Alexandr V. Matyukhin
}

A.N. Severtsov Institute of Ecology and Evolution, Moscow, Russia

*corresponding author; e-mail: sasha_djedi@mail.ru

\begin{abstract}
A Promyialges pari Fain, 1965 (Analgoidea: Epidermoptidae) feather mite was found on the louse fly Ornithomya avicularia L., 1758 (Diptera: Hippoboscidae), recovered from Eurasian rook, Corvus frugillegus L., 1758 (Passeriformes: Corvidae), in the south of European Russia. This is the first record of $P$. pari in Russia and on the aforementioned bird host.
\end{abstract}

KEY WORDS: Feather mites, Promyialges pari, Ornithomya avicularia, Diptera, host associations, fauna, Aves.

DOI: 10.21684/0132-8077-2021-29-1-17-22

\section{INTRODUCTION}

Feather mites of the family Epidermoptidae (Astigmata: Analgoidea) are permanent and highly specialized ectoparasites of birds. Throughout all of their life stages, epidermoptids live on the skin of avian hosts, slowly moving over the surface or penetrating into the epidermis (Dubinin 1953; Fain 1965; Mironov 1987, 1999; Gaud and Atyeo 1996). Since epidermoptids may cause various mange-like diseases in bird hosts, this feather mite family is of a high veterinary importance (Dubinin, 1953; Fain 1965; Gilardi et al. 2001). All representatives of the Myialginae subfamily, as well as of three Epidermoptinae subfamily genera (Metamichrolichus Fain, 1965, Microlichus Trouessart et Neumann, 1888 and Promyialges Fain 1964) have phoretic relationships with louse flies (Diptera: Hippoboscidae) and chewing lice (Phthiraptera) that parasitize birds (Fain 1965; Philips and Fain 1991). Fertilized females of these mites use louse flies and chewing lice to disperse and to infect birds. Females of the Myialginae subfamily and of the Promyialges genus lay eggs on the cuticles of the aforementioned insects, around the place of attachment, on the abdomen or on the basal parts of wings. Moreover, the representatives of the subfamily Myialginae are hyperparasites: females gnaw through cuticles with their chelicerae and feed on the hemolymph of insects. While feeding, the hysterosoma of these mites significantly expands, and females begin to lay eggs (Cooreman 1944; Büttiker 1948; Dubinin 1950; Furman and Tarshis 1953; Hiregaudar 1956, 1957; Evans et al. 1963; Hill et al. 1967; Büttiker and Černy 1974; Madden and Harmon 1998; Mironov et al. 2005; Whiteman et al. 2006; Macchioni 2007; Valim and
Gazeta 2007; Marcelino et al. 2009; Yamauchi and Kuroki 2009; Goater et al. 2018).

The genus Promyialges Fain, 1964 (Epidermoptinae), whose representatives only disperse with louse flies, was originally established by Fain (1964) for a single species, Microlichus uncus Vitzthum, 1934. In the revision of the family Epidermoptidae, Fain (1965) placed this taxon into the genus Myialges Trouessart, 1906 as a subgenus with 6 species: $M$. (P) cooremani Fain, 1965; M. (P). falconis Fain, 1965; M. (P). lophortyx (Furman et Tarshis, 1953); M. (P). macdonaldi Evans, Faim et Bafort, 1963; M. (P). pari Fain, 1965; M. (P). uncus (Vitzthum, 1934) (Fain 1965). Subsequently, Promyialges was again elevated to the status of a genus, while two of its species$M$. (P). cooremani and M. (P). macdonaldi-have been moved into separate genera (Mironov et al. 2005). Recently, one more species-P. italicus Faradonbeh et al., 2019 - has been described from Italy (Faradonbeh et al. 2019).

Our study presents the first record of the epidermoptid mite Promyialges pari in Russia and new data on its host associations and egg laying.

\section{MATERIALS AND METHODS}

The primary material (louse flies Ornithomya avicularia L., 1758) (Diptera: Hippoboscidae) has been collected in June, 2013 near Rostov-on-Don, Russia $\left(47^{\circ} 13.881^{\prime} \mathrm{N}, 39^{\circ} 43.3968^{\prime} \mathrm{E}\right)$ from the Eurasian rook Corvus frugillegus L., 1758 (Passeriformes: Corvidae) and fixed in vials with $96 \%$ ethanol. The flies were identified and examined for the presence of epidermoptids. The mites, after being removed from flies, were mounted on slides 


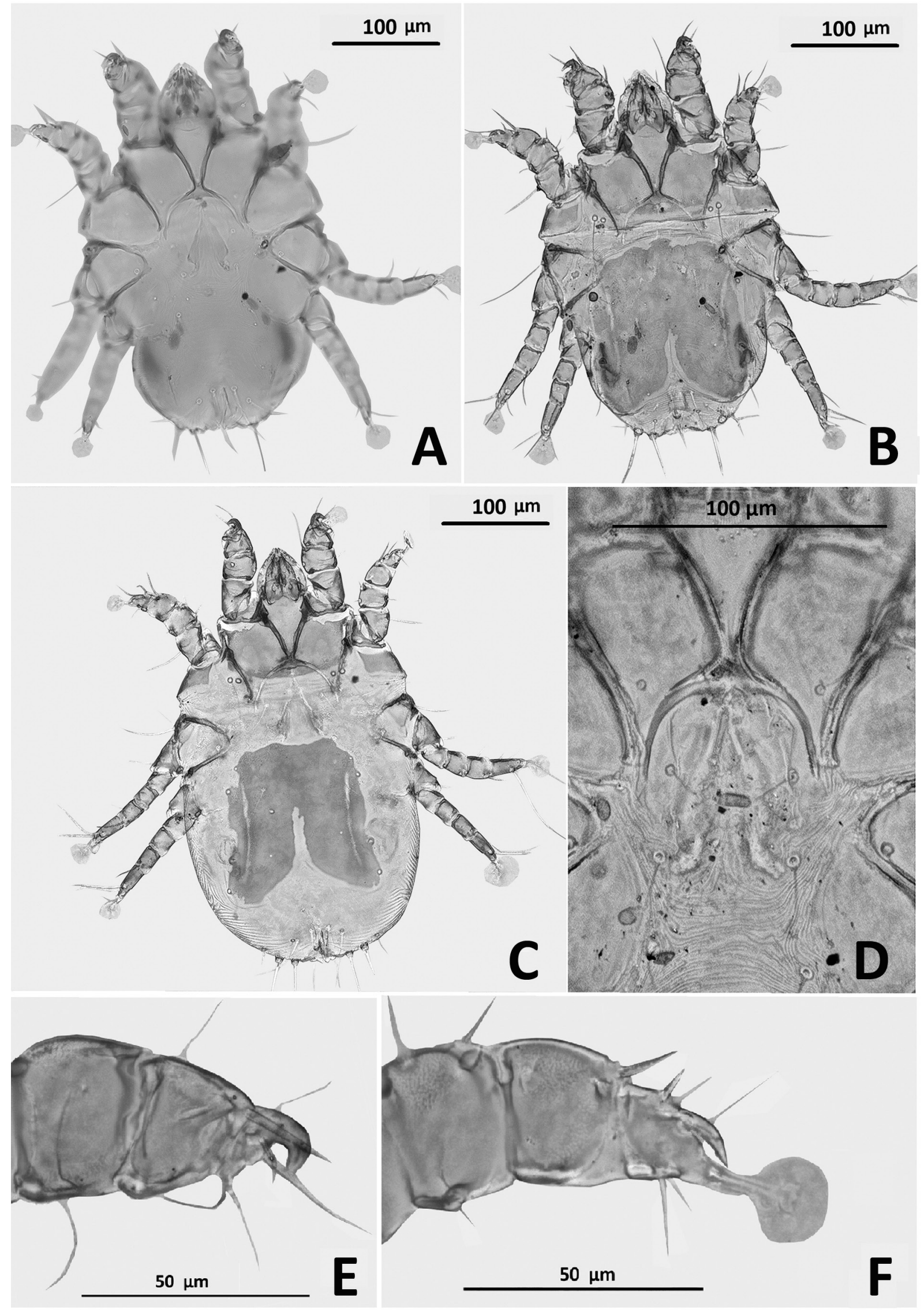

Fig. 1. Promyialges pari, female. A-non-engorged female, ventral view; B-non-engorged female, dorsal view; $\mathrm{C}$ - engorged female, dorsal view; D — epigynium and oviporus; E — tibia and tarsus; I, F—genu, tibia and tarsus II. 
in Hoyer's medium according the standard technique used for small mites (Krantz and Walter 2009) and examined with a Keyence microscope BZ-9000 (Keyence, Japan).

The identification of mite species was made using a key by Fain (1965) and the identification of flies species was based on the keys by Maa (1969a) and Doszhanov (1980; 2003). All mite and fly specimens have been deposited in the collection of A.N. Severtsov Institute of Ecology and Evolution (Moscow, Russia).

\section{RESULTS AND DISCUSSION}

A total of 13 Ornithomya avicularia louse fly females, bearing epidermoptid mites have been collected. On each fly, one Promyialges pari female (Fig. 1) surrounded by a wreath of eggs was found attached to the cuticle, on the ventral surface of the basal part of the wing. The number of eggs in each wreath varied from 3 to 13 (Table 1).

Representatives of $P$. pari were initially found on the skin of the Great tit Parus major L., 1758 (Passeriformes: Paridae) in Belgium by Fain (1965). Later on, this mite species was found in different parts of the world, mainly in the Eastern Hemisphere from a wide spectrum of birds belonging to the orders Coraciformes, Cuculiformes, Falconiformes, Galliformes and Passeriformes (Table 2). It is necessary to note that in some cases (Philips and Fain 1991), researchers doubted their identification of mites as $P$. pari, in particular, the specimens collected in Colombia, Papua New Guinea and Central Africa. Herein, P. pari is recorded for the first time in European Russia, as well as from C. frugilegus as an avian host.

Ornithomya avicularia - a common insect host of P. pari in western Europe-is a polyhostal fly species, distributed widely in the Palearctic region from western Europe to the Russian Far East and from central Karelia to northern Africa. It parasitizes a wide spectrum of Northern Palearctic birds, including various Corvidae (Thompson 1936, 1939; Maa 1969a, 1969b: Doszhanov 1980, 2003; Matyukhin 2010; Matyukhin et al. 2016, 2017). In particular, according to Maa (1969b), O. avicularia parasitizes 65 genera of birds, distributed across 23 families and 9 orders. In Israel, this louse fly was recorded on Turdus merula L., 1758 (Bear and Freidberg 1995); in Kazakhstan, Central Asia, and Western Siberia - on 81 species of birds from 24 families and 9 orders (Doszhanov 2003); in the Middle Volga region (Russia) — on 42 species from 19 families (Boyko et al. 1973). In the Pa- laearctic region, O. avicularia parasitizes 67 bird species, distributed across 59 genera, 28 families and 11 orders. Nine of the 67 species are from the Corvidae family: Corvus corax L., 1758, C. corone L., 1758, C. cornix L., 1758, C. frugillegus L. 1758, C. monedula L., 1758, Nucifraga caryocatactes (L., 1758), Pica pica (L.), 1758, Garrulus glandarius (L., 1758) and Perisoreus infaustus (L., 1758) (Matyukhin et al. 2014). Therefore, the finding of $P$. pari in the Rostov Region (European Russia) shows that this species is distributed in Europe much further to the east than was previously thought. This fact encourages further studies of epidermoptids, which disperse with louse flies and are potentially able to infect a wide spectrum of hosts, including domestic poultry.

\section{ACKNOWLEDGEMENTS}

The authors thank A. V. Zabashta (Rostov-onDon, Russia) for his help in the field with collecting birds and louse flies.

\section{REFERENCES}

Bear, F. and Freidberg, F. 1995. Contribution to the knowledge of the Ornithonyinae of Israel. The Israel Journal of Zoology, 41 (2): 109-124.

Boyko, A.V., Ayupov, A.S. and Ivliev, V.G. 1973. Krovososki (Diptera, Hippoboscidae) ptits v prirodnykh ochagakh kleshchevogo entsefalita lesostepnoy zony srednego Povolzhya [Bird louse flies (Diptera, Hippoboscidae) in natural nidi of the tick-borne encephalitis in the forest-steppe zone of the Middle Povolzhye]. Parasitology, 7(6): 536-540. [In Russian].

Büttiker, W. 1948. Phoresiebei Lausfliegen. Mitteilungen der Schweizerischen Entomologischen Gesellschaft, 21: 481 .

Buttiker, W. and Černý, V. 1974. Phoresiebei Hippobosciden (Diptera) von Säugetieren und Vögeln in der Schweiz. Mitteilungen der Schweizerischen Entomologischen Gesellschaft, 47: 319-326.

Cooreman, J. 1944. Un nouveau cas d'hyperparasitisme parmi les Acaridiae: Myialgopsis trinotoni n. gen. n.sp. parasite d'un Mallophage. Bulletin du Musée royal d'histoire naturelle de Belgique, 20(26): 1-12.

Doszhanov, T.N. 1980. Mukhi-krovososki (Diptera, Hippoboscidae) Kazakhstana [Louse Flies (Diptera, Hippoboscidae) in Kazakhstan]. Nauka, Alma-Ata, 280 pp. [In Russian]

Doszhanov, T.N. 2003. Mukhi-krovososki (Diptera, Hippoboscidae) Palearktiki [Louse Flies (Diptera, Hippoboscidae) of the Palearctic Region]. Nauka, Alma-Ata, 277 pp. [In Russian]

Dubinin, V.B. 1950. Kleshchi podsemeystva Myialgesinae, parazitiruyushchiye na mukhakh-krovosos- 
kakh i pukhoyedakh [Mites of the subfamily Myialgesinae on blood-sucking flies and bird lice]. Entomological Review, 31: 123-131. [In Russian].

Dubinin, V.B. 1953. Peryevye kleshchi (Analgesoidea). Chast II. Semeistva Epidermoptidae i Freyanida [=Feather mites (Analgesoidea). Part II. Families Epidermoptidae and Freyanidae]. Fauna SSSR, Paukoobraznye 6, Fasc. 6. Nauka, Moscow-Leningrad, 412 pp. [In Russian]

Evans, G.O., Fain, A. and Bafort, J. 1963. Découverte du cycle évolutif du genre IV (Myialges avec description d'une espece nouvelle (Myialgidae: Sarcoptiformes). Bulletin du Musée royal d'Histoire naturelle de Belgique, 99(34): 486-500.

Fain, A. 1964. Acariens Sarcoptiformes nouveaux diagnoses préliminaires. Revue de Zoologie et de Botanique africaines, 59: 183-188.

Fain, A. 1965. A review of the family Epidermoptidae Trouessart parasitic on the skin of birds (Acarina: Sarcoptiformes). Verhandelingen Van De Koninklijke Vlaamse Academie Voor Wetenschppen, Letteren en Schone Kunsten Van Bergie, 84: 1-176 (Part I); 1-144 (Part II).

Fain, A. and Grootaert, P. 1996. Observations sur des Acariens (Acari: Epidermoptidae) parasites d'Ornithomyia avicularia (L.) (Diptera: Hippoboscidae) de Belgique. Bulletin et Annales de la Société royale belge d'Entomologie, 132: 183-186.

Faradonbeh, M.M., Ostovan, H., OConnor, B.M., Gheibi, M., Joharchi, O. and Macchioni, F. 2019. Promyialges italicus sp. nov. (Astigmata: Epidermoptidae) with redescriptions of mites of the families Epidermoptidae and Cheyletidae (Prostigmata) associated with Pseudolynchia canariensis (Diptera: Hippoboscidae) from Iran and Italy. Persian Journal of Acarology, 8(1): 27-46.

Furman, D.F. and Tarshis, I.B. 1953. Mites of the genera Myialges and Microlichus (Acarina: Epidermoptidae) from avian and insect hosts. Journal of Parasitology, 39(1): 70-78.

Gaud, J. and Atyeo, W.T. 1996. Feather mites of the World (Acarina, Astigmata): the supraspecific taxa. Musée Royal de l'Afrique Centrale, Annales, Sciences Zoologiques, 277: 1-193 (Pt. 1, text); 1-436 (Pt. 2, illustrations).

Gilardi, K.V., Gilardi, J.D., Frank, A., Goff, M.L. and Boyce, W.M. 2001. Epidermoptid mange in Laysan albatross fledglings in Hawaii. Journal of Wildlife Diseases, 37 (1): 185-188.

Goater, C.P., Dyck J., Proctor H. and Floate, K.D. 2018. Hyperparasitism of an Avian Ectoparasitic Hippoboscid Fly, Ornithomya anchineuria, by the Mite, Myialges cf. Borealis, in Alberta, Canada. Journal of Parasitology, 104(2): 111-116.
Hill, D.S., Wilson, N. and Corbet, G.B. 1967. Mites associated with British species of Ornithomya (Diptera: Hippoboscidae). Journal of Medical Entomology, 4:102-122.

Hiregaudar, L. S. 1956. A record of Myialges anchora (Myialgesidae) on Pseudolynchia maura (Hippoboscidae) from India. Indian Veterinary Journal, 33: 134-135.

Hiregaudar, L.S. 1957. A new species of Myialgesid mite parasitic on Pseudolynchia maura (Diptera: Hippoboscidae) from India. Proceedings of the Indian Science Congress, 43(4): 29.

Krantz, G. and Walter, D. (Eds.). 2009. A Manual of Acarology. $3^{\text {rd }}$ edition. Texas Tech University Press, Lubbock, TX, USA, 807 pp.

Maa, T.C. 1969a. Revision of Icosta (=Lynchia Auctt.) with erection of a related genus Phthona (Diptera: Hippoboscidae). Pacific Insects Monographs, 20: 25-203.

Maa, T.C. 1969b. A revised checklist and concise host index of Hippoboscidae (Diptera). Pacific Insects Monographs, 20: 261-299.

Macchioni, F. 2007. Importance of phoresy in the transmission of Acarina. Parassitologia, 49 (1-2): 17-22.

Madden, D. and Harmon, W.M. 1998. First record and morphology of Myialges caulotoon (Acari: Epidermoptidae) from Galapagos hosts. Journal of Parasitology, 84(1): 186-189.

Marcelino, V.J.F.C., Arcoverde, A. R. and Daemon, E. 2009. Phoretic association of the mites Myialges spp. (Astigmata: Epidermoptidae) and Ornitocheyletia hallae Volgin (Prostigmata: Cheyletidae) with the fly Pseudolynchia canariensis (Macquart) (Diptera: Hippoboscidae). Neotropical Entomology, 38(5): 578-581.

Matyukhin, A.V. 2010. [Louse flies (Hippoboscidae) of Eastern Europe]. In: I. V. Skilsky, N. A. Smirnov (Eds.). Problems of Study and Protection of Fauna in Natural and Anthropogenic Ecosystems. Proceedings of the International Scientific Conference Dedicated to the $50^{\text {th }}$ Anniversary of the Regional Digest Fauna of the Soviet Bukovina (13 November, 2009, Chernivtsi, Ukraine). Druk Art, Chernivtsi, pp. 7-11. [In Russian]

Matyukhin, A.V., Zabashta, A. V. and Boyko, E.A. 2014. Ornithomya avicularia (Diptera: Hippoboscidae, Ornithomyinae) v Evrope [Ornithomya avicularia (Diptera: Hippoboscidae, Ornithomyinae) in Europe]. In: I.V. Skilsky (Ed.). Regional Aspects of Floral and Faunal Studies. Proceedings of the First International Scientific Conference (Putyla, Ukraine). Druk Art, Chernivtsi, pp. 130-134. [In Russian]

Matyukhin, A.V., Zabashta, A.V. and Boyko, E.A. 2016. Ornithomya fringillina (Diptera: Hippobos- 
cidae) v Vostochnoy Evrope [Ornithomya fringillina (Diptera: Hippoboscidae) in Eastern Europe]. In: I. V. Skilsky, A.V. Yuzyk (Eds.). Regional Aspects of Floral and Faunal Studies. Proceedings of the Third International Scientific Conference (Putyla, Ukraine). Druk Art, Chernivtsi, pp. 266269. [In Russian]

Matyukhin, A.V., Artemiev, A.V. and Panov, I.N. 2017. Parazitologicheskiye issledovaniya ptits: mukhikrovososki (Hippoboscidae, Ornithomyinae) Karelii [Parasitological studies of birds: louse-flies (Diptera: Hippoboscidae) in Karelia]. Proceedings of the Karelian Scientific Center of the Russian Academy of Sciences, Biogeographyseries, 7: 60-72. [In Russian]

Mironov, S.V. 1987. Morfologicheskiye adaptatsii peryevykh kleshchey k razlichnym tipam opereniya i kozhnym pokrovam ptits [Morphological adaptations of feather mites to different types of plumage and skin of birds]. Parazitologicheskii Sbornik, 34: 114-132. [In Russian with English summary]

Mironov, S. V. 1999. Feather mites: general morphological adaptations, phylogeny and coevolutionary relationships with birds. Ekologija (Vilnius, Lithuania), 2: 57-66.

Mironov, S.V., Bochkov, A.V. and Fain A. 2005. Phylogeny and evolution of parasitism in feather mites of the families Epidermoptidae and Dermationidae (Acari: Analgoidea). Zoologischer Anzeiger, 243: 155-179.

Philips, J.R. and Fain, A. 1991. Acarine symbionts of louse flies (Diptera: Hippoboscidae). Acarologia, 32: 377-384.
Thompson, G.B. 1936. 1) Some new records of the occurrence of Myialges spp. (Acarina); 2) A new Record of Microlichus uncus Vitzthum. Annals and Magazine of Natural History, 10(18): 315-320.

Thompson, G.B. 1939. Further records of the occurrence of Myialges and Microlichus (Acarina) on Mallophaga and Hippoboscidae. Annals and Magazine of Natural History, 11(3): 285-287.

Valim, M.P. and Gazeta, G. S. 2007. Phoretic association of the mites Myialges anchora Sergent and Trouessart (Acaridida, Epidermoptidae) and Ornithocheyletia hallae Smiley (Actinedida, Cheyletiellidae) with Pseudolynchia canariensis (Macquart) (Diptera, Hippoboscidae). Revista Brasileira de Entomologia, 51(4): 518-519.

Walter, G. 1989. Phoresy and hyperparasitism in $\mathrm{Or}$ nithomya (Diptera;Hippoboscidae) in the Federal Republic of Germany. Angewandte Parasitologie, 30(1): 43-46.

Whiteman, N.K., Sánchez, P., Merkel, J., Klompen, H. and Parker, P.G. 2006. Cryptic host specificity of an avian skin mite (Epidermoptidae) vectored by louse flies (Hippoboscidae) associated with two endemic Galapagos bird species. Journal of Parasitology, 92(6): 1218-1228.

Yamauchi, T. and Kuroki, T. 2009. Occurrence of Epidermoptid mites (Acari: Astigmata: Epidermoptidae) in Japan, with its hyperparasitic record on the Louse Fly Ornithomya avicularia aobatonis (Diptera: Hippoboscidae). Comparative Parasitology, 76(1): 93-99.

Table 1

Number of Promyialges pari females and the number of eggs in their clutches.

\begin{tabular}{|l|l|}
\hline Eggs in clutch, $\mathbf{n}$ & Females, $\mathbf{n}$ \\
\hline 3 & 3 \\
\hline 5 & 4 \\
\hline 9 & 4 \\
\hline 11 & 1 \\
\hline 13 & 1 \\
\hline
\end{tabular}

Table 2

Host associations and distribution of Promyialges pari.

\begin{tabular}{|l|l|l|l|l|}
\hline Louse fly species & Bird species & Bird family & Locality & Reference \\
\hline $\begin{array}{l}\text { Ornithomyia avicularia } \\
\text { L., } 1758\end{array}$ & Parus major L., 1758 & Paridae & Belgium & Fain 1965 \\
\hline “ & Periparus ater (L. 1758) & Paridae & Belgium & Fain 1965 \\
\hline
\end{tabular}


A. A. Yatsuk and A. V. Matyukhin

\begin{tabular}{|c|c|c|c|c|}
\hline “ & $\begin{array}{l}\text { Turdus philomelus } \\
\text { Brehm, } 1831\end{array}$ & Turdidae & Belgium & Fain, 1965 \\
\hline “ & T. viscivorus L., 1758 & Turdidae & Belgium & Fain 1965 \\
\hline “ & T. merula L., 1758 & Turdidae & Belgium & Fain and Grootaert 1996 \\
\hline “ & unknown & unknown & Germany & Walter, 1989 \\
\hline “ & Corvus frugilegus L. 1758 & Corvidae & Russia & Present study \\
\hline $\begin{array}{l}\text { O. fusciventris } \\
\text { Wiedemann, } 1830\end{array}$ & $\begin{array}{l}\text { Tangara arthus aurulenta } \\
\text { Lafresnaye, } 1843\end{array}$ & Thraupidae & Colombia* & Philips and Fain 1991 \\
\hline $\begin{array}{l}\text { Ornithoica exilis } \\
\text { Walker, } 1861\end{array}$ & $\begin{array}{l}\text { Halcyon chloris tristrami } \\
\text { Layard, } 1880\end{array}$ & Alcedinidae & $\begin{array}{l}\text { Papua New Guinea: } \\
\text { New Britain* }\end{array}$ & Philips and Fain 1991 \\
\hline “ & $\begin{array}{l}\text { H. cinnamomina reichen- } \\
\text { bachi Swainson, } 1821\end{array}$ & Alcedinidae & $\begin{array}{l}\text { FS of Micronesia: } \\
\text { Pohnpei }\end{array}$ & Philips and Fain 1991 \\
\hline $\begin{array}{l}\text { Ornithophila metallica } \\
\text { Schiner, } 1864\end{array}$ & Ammoperdix sp. & Phasianidae & Turkey & Philips and Fain 1991 \\
\hline ““ & Falco tinnunculus L., 1758 & Falconidae & Cyprus & Philips and Fain 1991 \\
\hline “ & $\begin{array}{l}\text { Halcyon chloris tristrami } \\
\text { Layard, } 1880\end{array}$ & Alcedinidae & $\begin{array}{l}\text { Papua New Guinea: } \\
\text { New Britain* }\end{array}$ & Philips and Fain 1991 \\
\hline “ & $\begin{array}{l}\text { Lonchura cucullata } \\
\text { Swainson, } 1837\end{array}$ & Estrildidae & Congo* & Philips and Fain 1991 \\
\hline “" & Corvus corone L., 1758 & Corvidae & Egypt & Philips and Fain 1991 \\
\hline “، & $\begin{array}{l}\text { Cuculus solitaries } \\
\text { Stephens, } 1815\end{array}$ & Cuculidae & Congo* & Philips and Fain 1991 \\
\hline “ & Motacilla alba L., 1758 & Motacillidae & Afghanistan & Philips and Fain 1991 \\
\hline “، & $\begin{array}{l}\text { Malaconotus blanchoti } \\
\text { Stephens, } 1826\end{array}$ & Malaconotidae & Uganda & Philips and Fain 1991 \\
\hline
\end{tabular}

${ }^{*}$ Researchers doubted their identification of mites from this locality as P. pari. 